\title{
Water Resources of Caldwell Parish, Louisiana
}

\section{Introduction}

Information concerning the availability, use, and quality of water in Caldwell Parish, Louisiana (fig. 1), is critical for proper water-supply management. The purpose of this fact sheet is to present information that can be used by water managers, parish residents, and others for stewardship of this vital resource. Information on the availability, past and current use, use trends, and water quality from groundwater and surface-water sources in the parish is presented. Previously published reports (see References Cited section) and data stored in the U.S. Geological Survey's National Water
Information System (http://waterdata.usgs.gov/nwis) are the primary sources of the information presented here.

In 2010, about 4.39 million gallons per day (Mgal/d) of water were withdrawn in Caldwell Parish, including about 2.67 Mgal/d from surface-water sources and $1.73 \mathrm{Mgal} / \mathrm{d}$ from groundwater sources ${ }^{1}$ (table 1). Withdrawals for various use categories are presented in table 2 . Water-use data collected at 5-year intervals from 1960 to 2010 (fig. 2) indicated that water withdrawals peaked in 1980 .

${ }^{1}$ Tabulation of numbers in text and tables may result in different totals because of rounding; nonrounded numbers are used for calculation of totals.

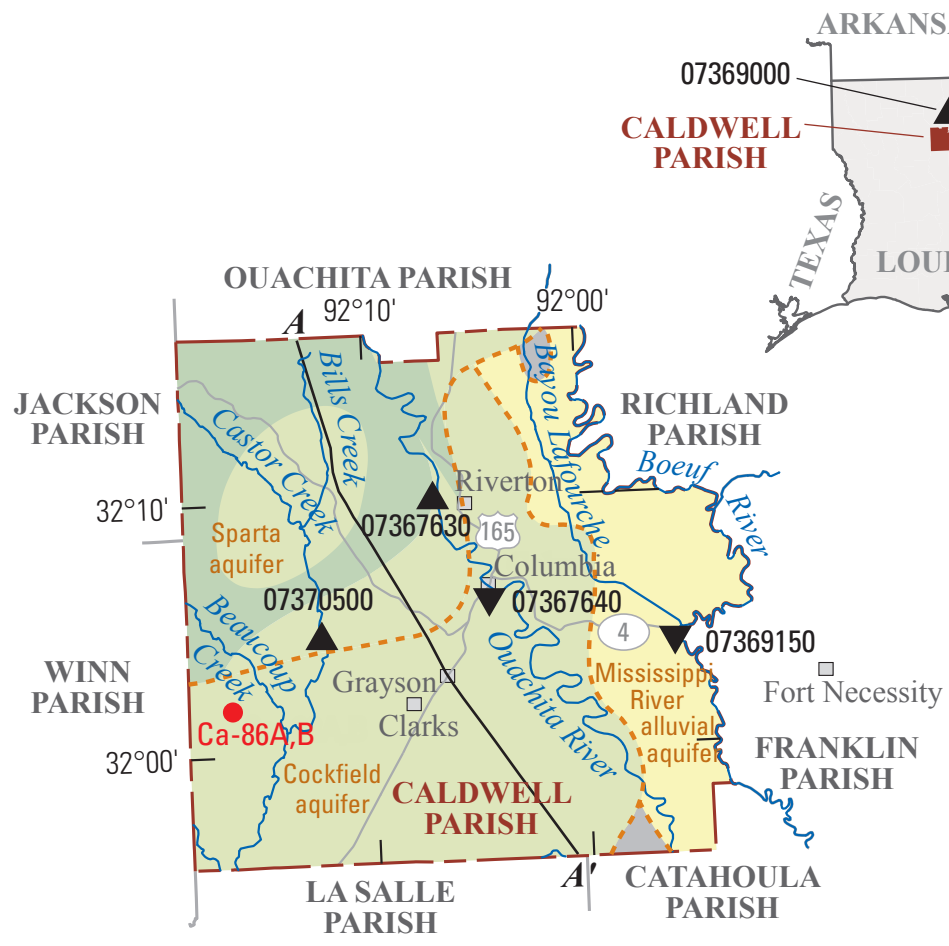

Base modified from U.S. Geological Survey digital data Albers Equal-Area Conic projection North American Datum of 1983 \begin{tabular}{llllll}
0 & 2 & 4 & 6 & 8 & 10 \\
\hline & & MILES
\end{tabular}

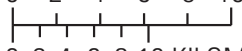
0246810 KILOMETERS

\section{EXPLANATION}

Approximate altitude of base of fresh groundwater, in feet below National Geodetic Vertical Datum of 1929 (modified from Smoot, 1988) 0 to 49

50 to 499

500 to 899

Approximate area where no major aquifer contains freshwater

$=-=-$ Approximate boundary of area showing deepest freshwater contained within Mississippi River alluvial, Cockfield, and Sparta aquifers

$A-A^{\prime}$ Line of section (see fig. 3)

- Well for which hydrograph is shown Ca-86A,B (see fig. 4)

$\Delta \quad$ U.S. Geological Survey surface-water 07367630 discharge site and number (see table 4)

U.S. Geological Survey surface-water quality site and number (see table 4)

Figure 1. Location of study area, Caldwell Parish, Louisiana. 
Table 1. Water withdrawals, in million gallons per day, by source in Caldwell Parish, Louisiana, 2010 (modified from Sargent, 2011).

\begin{tabular}{lcc}
\hline $\begin{array}{c}\text { Aquifer or surface- } \\
\text { water body }\end{array}$ & Groundwater & Surface water \\
\hline $\begin{array}{c}\text { Mississippi River } \\
\text { alluvial aquifer }\end{array}$ & 0.61 & \\
Cockfield aquifer & 1.09 & \\
Sparta aquifer & 0.02 & 2.67 \\
$\begin{array}{l}\text { Miscellaneous } \\
\text { streams }\end{array}$ & & \\
Total & 1.73 & 2.67 \\
\hline
\end{tabular}

Table 2. Water withdrawals, in million gallons per day, by use category in Caldwell Parish, Louisiana, 2010 (modified from Sargent, 2011).

\begin{tabular}{lccc}
\hline \multicolumn{1}{c}{ Use category } & Groundwater & $\begin{array}{c}\text { Surface } \\
\text { water }\end{array}$ & Total \\
\hline Public supply & 1.07 & 0.00 & 1.07 \\
Rural domestic & 0.07 & 0.00 & 0.07 \\
Livestock & 0.03 & 0.03 & 0.05 \\
Rice irrigation & 0.57 & 1.32 & 1.88 \\
General irrigation & 0.00 & 1.32 & 1.32 \\
\cline { 2 - 4 } Total & 1.73 & 2.67 & 4.39 \\
\hline
\end{tabular}

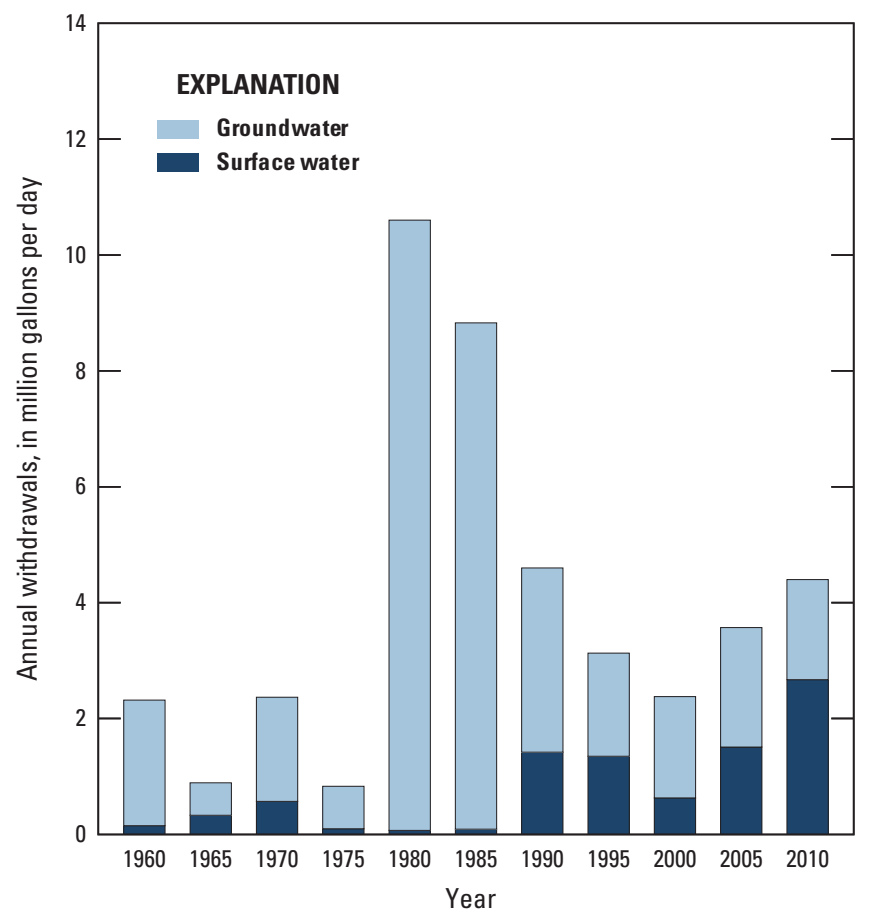

Figure 2. Water withdrawals in Caldwell Parish, Louisiana, 1960-2010 (Sargent, 2011).

\section{Groundwater Resources}

Fresh groundwater (water with a chloride concentration of 250 milligrams per liter [mg/L] or less) is available throughout Caldwell Parish except near the extreme southeastern corner of the parish. The base of freshwater is present at depths generally ranging from less than 100 to 800 feet (ft) below the National Geodetic Vertical Datum of 1929 (NGVD 29) (Smoot, 1988). The primary sources of fresh groundwater in Caldwell Parish are the Mississippi River alluvial aquifer and the Cockfield aquifer. A minor source of fresh groundwater underlying the parish is the Sparta aquifer (fig. 3, table 1). Recharge to aquifers in the parish is from precipitation, leakage from adjacent aquifers, and seasonal input from streams. Discharge from the aquifers is by evapotranspiration, natural seasonal flow into streams, leakage into adjacent aquifers, and withdrawals from wells.

State well-registration records listed 208 active water wells in Caldwell Parish in 2010, including 90 domestic, 78 irrigation, 33 public supply, and 7 industrial (Louisiana Department of Natural Resources, 2011). In 2010, categories of use for groundwater withdrawals included public supply, rural domestic, livestock, and rice irrigation (table 2 ).

\section{Mississippi River Alluvial Aquifer}

In Caldwell Parish, the Mississippi River alluvial aquifer is present from roughly the Ouachita River to the eastern boundary of the parish and ranges in thickness from less than 25 to $75 \mathrm{ft}$ (Ackerman, 1996). The base of the aquifer in the parish is an uneven surface that ranges in altitude from about 0 to $40 \mathrm{ft}$ or more below NGVD 29 (Whitfield, 1975). Freshwater is generally present throughout the alluvial aquifer in Caldwell Parish (fig. 1); however, small lenses of saltwater (water with a chloride concentration greater than $250 \mathrm{mg} / \mathrm{L}$ ) are locally present within the aquifer (Whitfield, 1975).

Recharge to the Mississippi River alluvial aquifer is primarily from precipitation and, to a lesser degree, by leakage from underlying sediments such as the Cockfield aquifer. Natural discharge occurs by seepage into streams (Whitfield, 1975). The direction of groundwater flow in the alluvial aquifer in Caldwell Parish is generally toward Bayou Lafourche and the Boeuf River (fig. 1). In 1990, water levels in the aquifer were generally $50 \mathrm{ft}$ or more above NGVD 29 along the Ouachita River in the northern part of the parish and less than $40 \mathrm{ft}$ above NGVD 29 along the Boeuf River in the southeastern corner of the parish (Seanor and Smoot, 1995).

State well-registration records listed 109 active wells screened in the Mississippi River alluvial aquifer in Caldwell Parish in 2010, including 2 public supply, 68 irrigation, 38 domestic, and 1 industrial well. Depths of these wells ranged from 27 to $130 \mathrm{ft}$ below land surface, with a median depth of $90 \mathrm{ft}$. Reported yields from wells screened in the Mississippi River alluvial aquifer in Caldwell Parish have ranged from 5 to 3,000 gallons per minute (gal/min) (Louisiana Department of Natural Resources, 2011). In 2010, groundwater withdrawals from the Mississippi River alluvial aquifer in Caldwell Parish totaled about $0.61 \mathrm{Mgal} / \mathrm{d}$ (table 1), and uses included about $0.03 \mathrm{Mgal} / \mathrm{d}$ for rural domestic, $0.02 \mathrm{Mgal} / \mathrm{d}$ for livestock, and $0.57 \mathrm{Mgal} / \mathrm{d}$ for rice irrigation.

A statistical summary of selected water-quality characteristics of freshwater samples from 10 wells screened in the Mississippi River alluvial aquifer in Caldwell Parish is listed in table 3. Freshwater from the aquifer generally is very hard. ${ }^{2}$ The data are limited but indicate that concentrations of iron and manganese greatly exceed the U.S. Environmental Protection Agency's Secondary Maximum Contaminant Levels ${ }^{3}$ (SMCLs) for drinking water.
${ }^{2}$ Hardness ranges, expressed as milligrams per liter of calcium carbonate, are as follows: 0-60, soft; 61-120, moderately hard; 121-180, hard; greater than 180, very hard (Hem, 1985).

${ }^{3}$ The SMCLs are nonenforceable Federal guidelines regarding cosmetic effects (such as tooth or skin discoloration) or aesthetic effects (such as taste, odor, or color) of drinking water. At high concentrations or values, health implications as well as aesthetic degradation might exist. SMCLs were established as guidelines for the States by the U.S. Environmental Protection Agency (1992). 


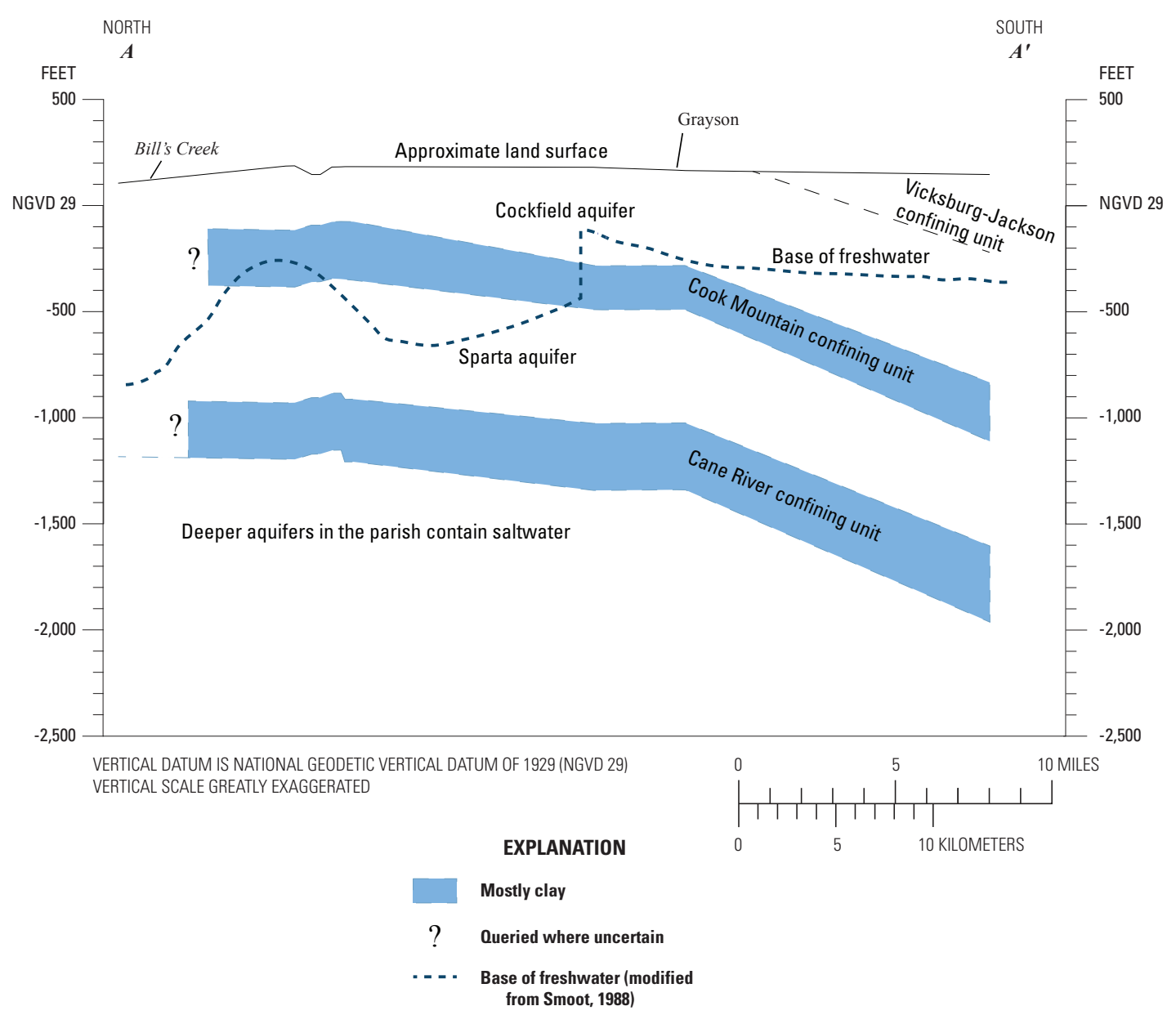

Figure 3. Generalized northto-south hydrogeologic section through Caldwell Parish, Louisiana, showing aquifer and confining unit intervals (individual sand and clay layers not shown) (modified from Huner, 1939 and Smoot, 1988). Trace of section shown on figure 1.

\section{Cockfield Aquifer}

The Cockfield aquifer is present throughout Caldwell Parish except in the northeastern corner of the parish where it is thin or absent (Ryals, 1984). The aquifer outcrops and receives recharge from precipitation west of the Ouachita River, except in the stream valleys of Castor Creek and its tributaries and in the southcentral part of the parish where the aquifer is overlain by clay of the Vicksburg-Jackson confining unit (Snead and McCulloh, 1984) (fig. 3). The Cook Mountain confining unit underlies the Cockfield aquifer.

In Caldwell Parish, the Cockfield aquifer dips to the southeast, and the base of the aquifer ranges in altitude from about $0 \mathrm{ft}$ below NGVD 29 in the northwestern corner of the parish to nearly 1,000 ft below NGVD 29 in the southeastern corner. Aquifer thickness ranges from less than $200 \mathrm{ft}$ along the northwestern parish line to $600-800 \mathrm{ft}$ in the southeastern corner of the parish (Ryals, 1984). The Cockfield aquifer generally contains freshwater in Caldwell Parish; however, in the southeastern corner and along the eastern margin of the parish, the aquifer contains saltwater (Brantly and Seanor, 1996; Ryals, 1984). The altitude of the base of freshwater within the Cockfield aquifer in central and southwestern Caldwell Parish is shown in figure 1.

The direction of groundwater flow in the Cockfield aquifer in Caldwell Parish is generally eastward toward the Ouachita River. In 1993, water levels were generally more than $140 \mathrm{ft}$ above NGVD 29 in the northwestern corner of the parish and about $60 \mathrm{ft}$ above NGVD 29 along the Ouachita River Valley (Brantly and Seanor, 1996). The water level in well Ca-86A (fig. 1 ), which is screened in the Cockfield aquifer, fluctuates from 2 to $6 \mathrm{ft}$ or more annually but has remained at about the same altitude since 2002 (fig. 4).
State well-registration records listed 75 active wells screened in the Cockfield aquifer in Caldwell Parish in 2010, including 39 domestic, 26 public supply, 6 industrial, and 4 irrigation wells. Depths of these wells ranged from 50 to $630 \mathrm{ft}$ below land surface, with a median depth of $335 \mathrm{ft}$. Reported yields from wells screened in the Cockfield aquifer in Caldwell Parish have ranged from 10 to $400 \mathrm{gal} / \mathrm{min}$ (Louisiana Department of Natural Resources, 2011). Water withdrawals from the Cockfield aquifer in Caldwell Parish totaled about $1.09 \mathrm{Mgal} / \mathrm{d}$ (table 1) in 2010, and uses included about $1.05 \mathrm{Mgal} / \mathrm{d}$ for public supply, $0.03 \mathrm{Mgal} / \mathrm{d}$ for rural domestic, and $0.01 \mathrm{Mgal} / \mathrm{d}$ for livestock.

A statistical summary of selected water-quality characteristics of freshwater from 54 wells screened in the Cockfield aquifer in Caldwell Parish is presented in table 3. Freshwater from the aquifer generally is soft and generally does not exceed the SMCLs for color, $\mathrm{pH}$, and concentrations of chloride and dissolved solids. Iron concentrations often greatly exceed the SMCL of 300 micrograms per liter $(\mu \mathrm{g} / \mathrm{L})$, and manganese concentrations generally exceed the SMCL of $50 \mu \mathrm{g} / \mathrm{L}$.

\section{Sparta Aquifer}

The Sparta aquifer is present throughout Caldwell Parish but contains freshwater only in the northwestern quadrant of the parish. The aquifer lies between massive clay beds of the underlying Cane River confining unit and the overlying Cook Mountain confining unit (fig. 3) (Rollo, 1960).

In Caldwell Parish, the Sparta aquifer dips to the southeast and the base of the aquifer ranges in altitude from about $800 \mathrm{ft}$ below NGVD 29 in the extreme northwestern corner of the parish to nearly 2,000 ft below NGVD 29 in the extreme southeastern corner. 
Table 3. Summary of selected water-quality characteristics of freshwater in the Mississippi River alluvial, Cockfield, and Sparta aquifers in Caldwell Parish, Louisiana (U.S. Geological Survey, 2012b).

[Values are in milligrams per liter, except as noted. ${ }^{\circ} \mathrm{C}$, degrees Celsius; PCU, platinum cobalt units; $\mu \mathrm{S} / \mathrm{cm}$, microsiemens per centimeter; SU, standard units; $\mathrm{CaCO}_{3}$, calcium carbonate; $\mu \mathrm{g} / \mathrm{L}$, micrograms per liter; - , insufficient data; SMCL, Secondary Maximum Contaminant Level established by the U.S. Environmental Protection Agency (2012); NA, not applicable; <, less than]

\begin{tabular}{|c|c|c|c|c|c|c|c|c|c|}
\hline & $\begin{array}{l}\text { Tempera- } \\
\text { ture }\left({ }^{\circ} \mathrm{C}\right)\end{array}$ & $\begin{array}{l}\text { Color, } \\
\text { (PCU) }\end{array}$ & $\begin{array}{c}\text { Specific } \\
\text { conductance, } \\
\text { field ( } \mu \mathrm{S} / \mathrm{cm} \\
\left.\text { at } 25^{\circ} \mathrm{C}\right) \\
\end{array}$ & $\begin{array}{l}\text { pH, } \\
\text { field } \\
\text { (SU) }\end{array}$ & $\begin{array}{l}\text { Hardness } \\
\text { (as } \\
\mathrm{CaCO}_{3} \text { ) }\end{array}$ & $\begin{array}{l}\text { Chloride, } \\
\text { filtered } \\
\text { (as CI) }\end{array}$ & $\begin{array}{c}\text { Iron, } \\
\text { filtered } \\
(\mu \mathrm{g} / \mathrm{L} \text { as } \mathrm{Fe})\end{array}$ & $\begin{array}{l}\text { Manganese, } \\
\text { filtered } \\
\text { ( } \mu \mathrm{g} / \mathrm{L} \text { as } \mathrm{Mn} \text { ) }\end{array}$ & $\begin{array}{l}\text { Dissolved } \\
\text { solids, } \\
\text { filtered }\end{array}$ \\
\hline \multicolumn{10}{|c|}{ Mississippi River alluvial aquifer, 1970-2011 (10 wells) } \\
\hline Median & 20.1 & 5 & 537 & 7.2 & 210 & 20 & 8,200 & 980 & 156 \\
\hline 10th percentile & 19.5 & - & 346 & - & 150 & 11 & 4,400 & 540 & - \\
\hline 90th percentile & 20.5 & - & 698 & - & 300 & 78 & 12,000 & 3,000 & - \\
\hline Number of samples & 9 & 1 & 7 & 2 & 8 & 10 & 8 & 7 & 1 \\
\hline $\begin{array}{l}\text { Percentage of samples } \\
\text { that do not exceed } \\
\text { SMCLs }\end{array}$ & NA & 100 & NA & 100 & NA & 100 & 0 & 0 & 100 \\
\hline \multicolumn{10}{|c|}{ Cockfield aquifer, 1939-89 (54 wells) } \\
\hline Median & 20.6 & 5 & 414 & 7.5 & 40 & 20 & 1,200 & 80 & 272 \\
\hline 10th percentile & 19.5 & 5 & 263 & 6.5 & 2 & 9.3 & 70 & 20 & 190 \\
\hline 90th percentile & 21.8 & 50 & 715 & 8.5 & 110 & 38 & 6,000 & 250 & 412 \\
\hline Number of samples & 14 & 41 & 38 & 40 & 54 & 54 & 34 & 23 & 37 \\
\hline $\begin{array}{l}\text { Percentage of samples } \\
\text { that do not exceed } \\
\text { SMCLs }\end{array}$ & NA & 78 & NA & 88 & NA & 100 & 29 & 35 & 92 \\
\hline \multicolumn{10}{|c|}{ Sparta aquifer, 1947-2012 (13 wells) } \\
\hline Median & 23.0 & 120 & 1,540 & 8.5 & 8 & 80 & 80 & $<1$ & 757 \\
\hline 10th percentile & 22.1 & 55 & 1,070 & 8.2 & 2 & 18 & 20 & $<1$ & 651 \\
\hline 90th percentile & 24.1 & 200 & 1,970 & 8.8 & 27 & 140 & 1,000 & 16 & 1,120 \\
\hline Number of samples & 5 & 8 & 10 & 8 & 12 & 13 & 8 & 5 & 6 \\
\hline $\begin{array}{l}\text { Percentage of samples } \\
\text { that do not exceed } \\
\text { SMCLs }\end{array}$ & NA & 0 & NA & 62 & NA & 100 & 75 & 100 & 0 \\
\hline \multicolumn{10}{|c|}{ SMCLs } \\
\hline & NA & 15 & NA & $6.5-8.5$ & NA & 250 & 300 & 50 & 500 \\
\hline
\end{tabular}

The thickness of the aquifer ranges from 600 to $800 \mathrm{ft}$ throughout the parish except in the southeastern corner, where the thickness is from 800 to 1,000 ft (Ryals, 1984). The altitude of the base of freshwater within the Sparta aquifer in northwestern Caldwell Parish is shown in figure 1.

In 2007, water levels in the Sparta aquifer in Caldwell Parish ranged from about $80 \mathrm{ft}$ above NGVD 29 in the southwestern corner of the parish to about $20 \mathrm{ft}$ below NGVD 29 in the northwestern corner (Schrader, 2008). Regional groundwater withdrawals have greatly affected the direction of groundwater flow in the Sparta aquifer. In Caldwell Parish, the direction of groundwater flow in the Sparta aquifer is northward toward a pumping center in Ouachita Parish (Schrader, 2008). The water level in well Ca-86B (fig. 1), which is screened in the Sparta aquifer in Caldwell Parish, declined about $8 \mathrm{ft}$ between 2002 and 2013 (fig. 4).
State well-registration records listed 14 active wells screened in the Sparta aquifer in Caldwell Parish in 2010, including 9 domestic and 5 public supply. Well depths ranged from 400 to $845 \mathrm{ft}$ below land surface, with a median depth of $525 \mathrm{ft}$. Reported yields from wells screened in the Sparta aquifer in Caldwell Parish have ranged from 2 to $140 \mathrm{gal} / \mathrm{min}$ (Louisiana Department of Natural Resources, 2011). In 2010, groundwater withdrawals from the Sparta aquifer in Caldwell Parish totaled about $0.02 \mathrm{Mgal} / \mathrm{d}$ (table 1), primarily for public supply.

A statistical summary of selected water-quality characteristics of freshwater from 13 wells screened in the Sparta aquifer in Caldwell Parish is presented in table 3 . Freshwater from the aquifer generally is soft and generally does not exceed the SMCLs for concentrations of iron and manganese. Color and dissolved solids concentrations exceeded the SMCLs in sampled wells. The median value for $\mathrm{pH}$ is at the upper SMCL limit of 8.5 standard units, indicating that water in the Sparta aquifer tends to be alkaline. 


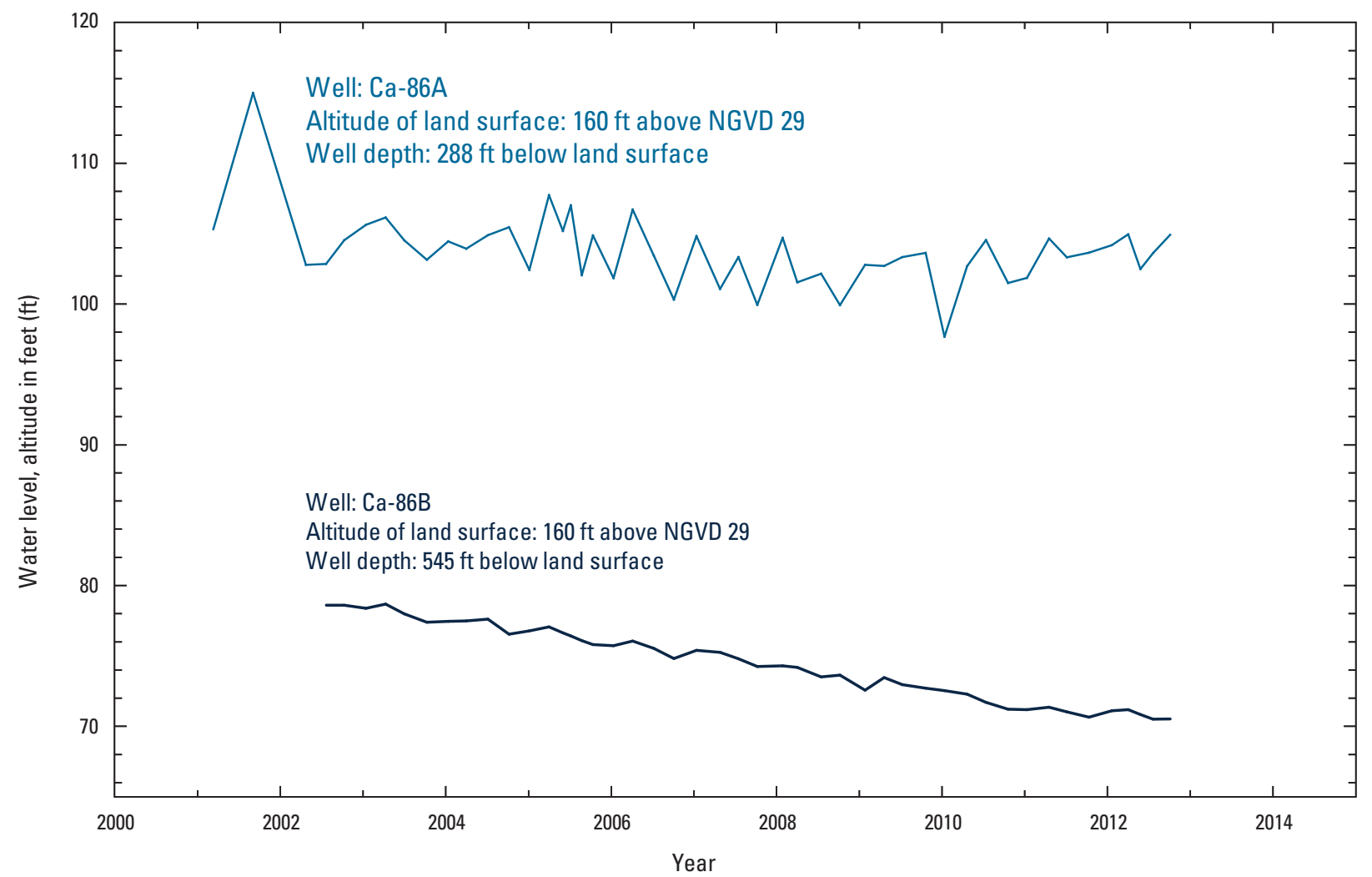

Figure 4. Water levels in well Ca-86A screened in the Cockfield aquifer and well Ca-86B screened in the Sparta aquifer in Caldwell Parish, Louisiana (see fig. 1 for well locations; U.S. Geological Survey, 2012a). Altitude of land surface and water level is measured in feet (ft) above the National Geodetic Vertical Datum of 1929 (NGVD 29).

\section{Surface-Water Resources}

In 2010, about $2.67 \mathrm{Mgal} / \mathrm{d}$ of surface water were withdrawn in Caldwell Parish, and uses included about $0.03 \mathrm{Mgal} / \mathrm{d}$ for livestock, $1.32 \mathrm{Mgal} / \mathrm{d}$ for rice irrigation, and $1.32 \mathrm{Mgal} / \mathrm{d}$ for general irrigation (tables 1 and 2). Notable surface-water bodies in the parish are the Ouachita River, Bayou Lafourche, Boeuf River, Castor Creek, and Beaucoup Creek (fig. 1). The average daily discharge for the Ouachita River at Columbia L\&D (Lock and Dam) near Riverton (site number 07367630; fig. 1) during 1982-87 was about 21,326 cubic feet per second $\left(\mathrm{ft}^{3} / \mathrm{s}\right)$. During 1940-71, the average daily discharge for Castor Creek near Grayson (site number 07370500) was $243 \mathrm{ft}^{3} / \mathrm{s}$. During 1938-2012, the average daily discharge for Bayou Lafourche near Crew Lake (site number 07369000), located roughly $16 \mathrm{mi}$ north-northeast of Caldwell Parish, was $1,818 \mathrm{ft}^{3} / \mathrm{s}$ (U.S. Geological Survey, 2013).

Water samples analyzed during 1974-93 (table 4) indicated that water in the Ouachita River at Columbia (site number 07367640) is soft and that samples generally do not exceed the SMCLs for $\mathrm{pH}$ and concentrations of chloride and sulfate. Dissolved oxygen is generally greater than $5 \mathrm{mg} / \mathrm{L}$, which is considered the minimum value for a diversified population of fresh, warmwater biota, including sport fish (Louisiana Department of Environmental Quality, 2008). Water samples analyzed during 1975-91 from the Boeuf River near Fort Necessity (site number 07369150; table 4) indicated that the median value for hardness fell within the moderately hard range and that samples generally do not exceed the SMCLs for $\mathrm{pH}$ and concentrations of chloride, sulfate, and iron. Dissolved oxygen concentrations are generally greater than $5 \mathrm{mg} / \mathrm{L}$.

\section{References Cited}

Ackerman, D.J., 1996, Hydrology of the Mississippi River valley alluvial aquifer, south-central United States: U.S. Geological Survey Professional Paper 1416-D, 56 p.

Brantly, J.A., and Seanor, R.C., 1996, Louisiana ground-water map no. 9Potentiometric surface, 1993, and water-level changes, 1968-93, of the Cockfield aquifer in northern Louisiana: U.S. Geological Survey WaterResources Investigations Report 95-4241, 2 sheets, accessed January 24, 2012, at http://pubs.er.usgs.gov/publication/wri954241.

Hem, J.D., 1985, Study and interpretation of the chemical characteristics of natural water (3d ed.): U.S. Geological Survey Water-Supply Paper 2254, 264 p., accessed February 20, 2013, at http://pubs.er.usgs.gov/publication/ wsp2254.

Huner, John, Jr., 1939, Geology of Caldwell and Winn Parishes: Department of Conservation, Louisiana Geological Survey, Geological Bulletin no. 15, $356 \mathrm{p}$.

Louisiana Department of Environmental Quality, 2008, Environmental Regulatory Code, Title 33, Part IX, Subpart 1: Baton Rouge, Louisiana Department of Environmental Quality, accessed December 27, 2012, at http:www.deq.louisiana.gov/portal/tabid/1674/Default.aspx.

Louisiana Department of Natural Resources, 2011, Strategic Online Natural Resources Information System (SONRIS): Louisiana Department of Natural Resources database, accessed February 14, 2011, at http://sonris.com/.

Rollo, J.R., 1960, Ground water in Louisiana: Department of Conservation, Louisiana Geological Survey, and Louisiana Department of Public Works, Water Resources Bulletin no. 1, 84 p.

Ryals, G.N., 1984, Regional geohydrology of the northern Louisiana saltdome basin, part II, geohydrologic maps of the Tertiary aquifers and related confining layers: U.S. Geological Survey Water-Resources Investigations Report 83-4135, 6 p., accessed December 27, 2012, at http://pubs.er.usgs. gov/publication/wri834135.

Sargent, B.P., 2011, Water use in Louisiana, 2010: Louisiana Department of Transportation and Development Water Resources Special Report no. 17, $135 \mathrm{p}$. 
Table 4. Summary of selected water-quality characteristics for the Ouachita and Boeuf Rivers in Caldwell Parish, Louisiana (U.S. Geological Survey, 2012b).

[Values are in milligrams per liter, except as noted. $\mu \mathrm{S} / \mathrm{cm}$, microsiemens per centimeter; ${ }^{\circ} \mathrm{C}$, degrees Celsius; $\mathrm{SU}$, standard units; $\mathrm{CaCO}_{3}$, calcium carbonate; $\mu \mathrm{g} / \mathrm{L}$, micrograms per liter; SMCL, Secondary Maximum Contaminant Level established by the U.S. Environmental Protection Agency (2012); NA, not applicable]

\begin{tabular}{|c|c|c|c|c|c|c|c|c|c|c|}
\hline & $\begin{array}{c}\text { Specific } \\
\text { conductance, } \\
\text { field }(\mu \mathrm{S} / \mathrm{cm} \\
\left.\text { at } 25^{\circ} \mathrm{C}\right)\end{array}$ & $\begin{array}{l}\text { Oxygen, } \\
\text { dissolved }\end{array}$ & $\begin{array}{l}\mathrm{pH} \text {, } \\
\text { field } \\
(\mathrm{SU})\end{array}$ & $\begin{array}{l}\text { Hard- } \\
\text { ness (as } \\
\mathrm{CaCO}_{3} \text { ) }\end{array}$ & $\begin{array}{l}\text { Calcium, } \\
\text { filtered } \\
\text { (as Ca) }\end{array}$ & $\begin{array}{l}\text { Mag- } \\
\text { nesium, } \\
\text { filtered } \\
\text { (as Mg) }\end{array}$ & $\begin{array}{l}\text { Sodium, } \\
\text { filtered } \\
\text { (as Na) }\end{array}$ & $\begin{array}{l}\text { Chloride, } \\
\text { filtered } \\
\text { (as CI) }\end{array}$ & $\begin{array}{l}\text { Sulfate, } \\
\text { filtered } \\
\text { (as } \mathrm{SO}_{4} \text { ) }\end{array}$ & $\begin{array}{c}\text { Iron, } \\
\text { filtered } \\
(\mu \mathrm{g} / \mathrm{L} \\
\text { as } \mathrm{Fe})\end{array}$ \\
\hline \multicolumn{11}{|c|}{ Ouachita River at Columbia, 1974-931 } \\
\hline Median & 168 & 7.2 & 6.7 & 31 & 8.4 & 2.1 & 19 & 29 & 13 & 280 \\
\hline 10th percentile & 88 & 4.7 & 6.1 & 19 & 5.0 & 1.3 & 8.3 & 13 & 6.8 & 110 \\
\hline 90th percentile & 324 & 10.3 & 7.2 & 48 & 14 & 3.1 & 40 & 61 & 23 & 550 \\
\hline Number of samples & 154 & 148 & 155 & 154 & 154 & 154 & 153 & 153 & 151 & 73 \\
\hline $\begin{array}{l}\text { Percentage of samples } \\
\text { that do not exceed } \\
\text { SMCLs }\end{array}$ & NA & NA & 66 & NA & NA & NA & NA & 100 & 100 & 62 \\
\hline
\end{tabular}

\begin{tabular}{|c|c|c|c|c|c|c|c|c|c|c|}
\hline \multicolumn{11}{|c|}{ Boeuf River near Fort Necessity, 1975-91² } \\
\hline Median & 395 & 7.7 & 7.2 & 100 & 26 & 8.3 & 34 & 53 & 16 & 100 \\
\hline 10th percentile & 87 & 4.9 & 6.4 & 25 & 6.6 & 2.0 & 6.4 & 7.0 & 6.0 & 10 \\
\hline 90th percentile & 1,040 & 10.6 & 7.8 & 200 & 50 & 18 & 130 & 210 & 32 & 280 \\
\hline Number of samples & 95 & 93 & 96 & 96 & 96 & 96 & 96 & 96 & 96 & 40 \\
\hline $\begin{array}{l}\text { Percentage of samples } \\
\text { that do not exceed } \\
\text { SMCLs }\end{array}$ & NA & NA & 88 & NA & NA & NA & NA & 96 & 100 & 90 \\
\hline \multicolumn{11}{|c|}{ SMCLS } \\
\hline & NA & NA & $6.5-8.5$ & NA & NA & NA & NA & 250 & 250 & 300 \\
\hline
\end{tabular}

\footnotetext{
${ }^{1}$ Site number 07367640.

${ }^{2}$ Site number 07369150 .
}

Schrader, T.P., 2008, Potentiometric surface in the Sparta-Memphis aquifer of the Mississippi Embayment, spring 2007: U.S. Geological Survey Scientific Investigations Map 3014, 1 sheet, accessed December 4, 2012, at http://pubs. er.usgs.gov/publication/sim3014

Seanor, R.C., and Smoot, C.W., 1995, Louisiana ground-water map no. 6Potentiometric surface, 1990, and water-level changes, 1974-90, of the Mississippi River alluvial aquifer in northeastern Louisiana: U.S. Geological Survey Water-Resources Investigations Report 95-4146, 2 sheets, accessed December 5, 2012, at http://pubs.er.usgs.gov/publication/wri954146.

Smoot, C.W., 1988, Louisiana hydrologic atlas map no. 3-Altitude of the base of freshwater in Louisiana: U.S. Geological Survey Water-Resources Investigations Report 86-4314, 1 sheet, accessed December 27, 2012, at http://pubs.er.usgs.gov/ publication/wri864314.

Snead, J.I., and McCulloh, R.P., comps., 1984, Geologic map of Louisiana: Baton Rouge, Louisiana Geological Survey, scale 1:500,000.

U.S. Environmental Protection Agency, 1992, Secondary Drinking Water Regulations - Guidance for nuisance chemicals: U.S. Environmental Protection Agency publication EPA 810/K-92-001, 4 p., accessed December 27, 2012, at http://water.epa.gov/drink/contaminants/secondarystandards.cfm.

U.S. Environmental Protection Agency, 2012, 2012 Edition of the drinking water standards and health advisories: U.S. Environmental Protection Agency publication EPA 822-S-12-001, Office of Water, 12 p., accessed December 27, 2012, at http://water.epa.gov/action/advisories/drinking/upload/ dwstandards2012.pdf.

U.S. Geological Survey, 2012a, Groundwater levels for Louisiana: National Water Information System Web Interface, accessed December 18, 2012, at http://nwis waterdata.usgs.gov/la/nwis/gwlevels.

U.S. Geological Survey, 2012b, Water quality samples for Louisiana: National Water Information System Web Interface, accessed December 19, 2012, at http:// nwis.waterdata.usgs.gov/la/nwis/qwdata.
U.S. Geological Survey, 2013, USGS surface-water daily statistics for the Nation: National Water Information System Web Interface, accessed November 19, 2013, at http://waterdata.usgs.gov/nwis.

Whitfield, M.S., Jr., 1975, Geohydrology and water quality of the Mississippi River alluvial aquifer, northeastern Louisiana: Louisiana Department of Public Works Water Resources Technical Report no. 10, 29 p.

This fact sheet was published by the U.S. Geological Survey, in cooperation with the Louisiana Department of Transportation and Development (DOTD). Thanks are given to Zahir "Bo" Bolourchi, Director, Water Resources Programs, DOTD, who contributed to the content of the fact sheet.

\section{By Lawrence B. Prakken and Vincent E. White}

\section{For additional information, contact:}

Director, USGS Louisiana Water Science Center

3535 S. Sherwood Forest Blvd., Suite 120

Baton Rouge, LA 70816

E-mail: dc_la@usgs.gov

Fax: (225) 298-5490

Telephone: (225) 298-5481

Home Page: http://la.water.usgs.gov 